\title{
PARTISIPASI PUBLIK DALAM PROSES KEBIJAKAN DI MASA REFORMASI
}

\author{
Ronald Hasibuan \\ Program Studi Ilmu Pemerintahan, Fakultas Ilmu Sosial dan Ilmu Politik \\ Universitas Riau Kepulauan, Batam, Indonesia \\ ronaldhsb@gmail.com
}

\begin{abstract}
Abstrak
Partisipasi publik adalah konsekuensi dari kehidupan demokrasi. Namun pada prakteknya peran serta masyarakat dalam partisipasi publik sering kali diabaikan. Padahal dikatakan dalam perundangundangan Negara wajib menyediakan ruang bagi peran serta publik terutama dalam proses penetapan kebijakan di era reformasi. Tulisan ini berusaha mendeskripsikan bagaimana pentingnya partisipasi publik, kendala-kendala yang dihadapi serta beberapa kemungkinan solusi untuk menyikapi kendalakendala yang ada. Pendekatan utama yang dilakukan adalah studi dokumentasi serta hasil pengamatan penulis dilapangan. Adapun kesimpulan dari tulisan ini memperlihatkan bahwa partisipasi publik akan terwujud apabila ada kesepahaman antara pemerintah dan masyarakat tentang pentingnya hal ini serta meningkatnya kapasitas tidak hanya pemerintah tetapi juga masyarakat.
\end{abstract}

Kata Kunci : partisipasi publik, reformasi, kebijakan publik

\begin{abstract}
Abstact
Public participation is a consequence of democratic life. But in practice community participation in public participation is often ignored. Even though it is said in the legislation that the State is obliged to provide space for public participation, especially in the process of policy making in the reform era. This paper attempts to describe the importance of public participation, the constraints faced and some possible solutions to address existing constraints. The main approach taken is the study of documentation and the authors' observations in the field. The conclusion of this paper shows that public participation will be realized if there is an understanding between the government and the community about the importance of this and the increased capacity of not only the government but also the community.
\end{abstract}

Keywords: public participation, reform, public policy 


\section{PENDAHULUAN}

Implementasi demokrasi merupakan amanat reformasi yang harus segera dipenuhi penyelenggaraannya di Republik Indonesia. Artinya demokrasi harus dijalankan tanpa embelembel seperti yang telah terjadi di masa lalu, seperti Demokrasi Terpimpin atau Dernokrasi Pancasila. Demokrasi adalah demokrasi.

Sebagai konsekuensi implementasi demokrasi adalah penyediaan ruang bagi partisipasi publik yang seluas-luasnya. Selama ini, partisipasi publik yang terfasilitasi hanya sebatas penggunaan hak pilih dalam pemilu dan pemberian kontribusi kepada negara melalui pembayaran pajak dan pungutan lain yang bersifat sah dan legal. Ruang partisipasi publik sesuai dengan keinginan masyarakat sendiri masih sangat minimalis, kalau tidak bisa dikatakan nihil. Untuk itu dalam upaya terwujudnya pemerintahan oleh, dari dan untuk rakyat, penulis melihat perlu perlu kiranya pemerintah mendorong bahkan memfasilitasi upaya pemberdayaan dan peningkatan partisipasi publik dalam penyelenggaraan kehidupan bernegara yang demokratis. Bagaimana sebaiknya upaya-upaya yang harus diperhatikan dan dilaksanakan adalah isu penting selanjutnya yang akan penulis utarakan dalam pembahasan tulisan ini.

\section{METODELOGI}

Adapun metode yang digunakan penulis adalah deskriptif kualitatif yaitu dengan memusatkan perhatian pada masalah-masalah yang ada pada saat penelitian dilakukan atau masalah-masalah yang bersifat aktual dan menggambarkan fakta-fakta tentang masalah yang diselidiki sebagaimana adanya dan diiringi dengan interpretasi rasional (Hadari, 1993). Dengan demikian diharapkan isu partisipasi dapat dikemukakan sebagaimana adanya secara lengkap dan diikuti dengan pemberian analisa dan interpretasi.

\section{PEMBAHASAN}

\section{Konsep Partisipasi Publik dalam Praktek Politik}

Sebelum berbicara praktek partisipasi dalam kehidupan demokrasi perlu kiranya diutarakan sekilas sebagai landasan teori tentang partisipasi. Pengertian partisipasi publik dalam studi ilmu politik dapat diartikan sebagai kegiatan warganegara yang bertujuan untuk mempengaruhi pengambilan keputusan politik. Dengan demikian partisipasi politik dilakukan orang dalam posisinya sebagai warganegara, bukan politikus ataupun pegawai negeri dan sifat partisipasi politik ini adalah sukarela, bukan dimobilisasi oleh negara ataupun partai yang berkuasa. 
Definisi partisipasi politik yang cukup senada disampaikan oleh Silvia Bolgherini. Menurut Bolgherini (dalam Calise and Lowi, 2010), partisipasi politik adalah:

" ... a series of activities related to political life, aimed at influencing public decisions in a more or less direct way-legal, conventional, pacific, or contentious".

Bagi Bolgherini, partisipasi politik adalah segala aktivitas yang berkaitan dengan kehidupan politik, yang ditujukan untuk memengaruhi pengambilan keputusan baik secara langsung maupun tidak langsung dengan cara legal, konvensional, damai, ataupun memaksa.

\section{Bentuk Partisipasi Politik}

Jika model partisipasi politik bersumber pada faktor "kebiasaan" partisipasi politik di suatu zaman, maka bentuk partisipasi politik mengacu pada wujud nyata kegiatan politik tersebut. Huntington dan Nelson (1990: 9-10) membagi bentuk-bentuk partisipasi politik menjadi:

1. Kegiatan Pemilihan yaitu kegiatan pemberian suara dalam pemilihan umum, mencari dana partai, menjadi tim sukses, mencari dukungan bagi calon legislatif atau eksekutif, atau tindakan lain yang berusaha mempengaruhi hasil pemilu;

2. Lobby yaitu upaya perorangan atau kelompok menghubungi pimpinan politik dengan maksud mempengaruhi keputusan mereka tentang suatu isu;

3. Kegiatan Organisas yaitu partisipasi individu ke dalam organisasi, baik selaku anggota maupun pemimpinnya, guna mempengaruhi pengambilan keputusan oleh pemerintah;

4. Contacting yaitu upaya individu atau kelompok dalam membangun jaringan dengan pejabatpejabat pemerintah guna mempengaruhi keputusan mereka, dan

5. Tindakan Kekerasan (violence) - yaitu tindakan individu atau kelompok guna mempengaruhi keputusan pemerintah dengan cara menciptakan kerugian fisik manusia atau harta benda, termasuk di sini adalah huru-hara, teror, kudeta, pembutuhan politik (assassination), revolusi dan pemberontakan.

Kelima bentuk partisipasi politik menurut Huntington dan Nelson telah menjadi bentuk klasik dalam studi partisipasi politik. Keduanya tidak membedakan apakah tindakan individu atau kelompok di tiap bentuk partisipasi politik legal atau ilegal. Sebab itu, penyuapan, ancaman, pemerasan, dan sejenisnya di tiap bentuk partisipasi politik adalah masuk ke dalam kajian ini. Klasifikasi bentuk partisipasi politik Huntington dan Nelson belumlah relatif lengkap karena keduanya belum memasukkan bentuk-bentuk partisipasi politik seperti kegiatan diskusi politik, 
menikmati berita politik, atau lainnya yang berlangsung di dalam skala subyektif individu. Thomas M. Magstadt menyebutkan bentuk-bentuk partisipasi publik dapat meliputi: Opini publik; Polling; Pemilihan umum; dan Demokrasi langsung (Magstadt, 2012: 82).

\section{Demokrasi yang Bermakna dan Hakiki}

Dua Belas Tahun tahun sudah bangsa ini menikmati demokrasi setelah keruntuhan otoritarianisme. Beberapa bentuk kebebasan dapat dinikmati dan dirasakan rakyat. Di antaranya yang menonjol ialah pertama, kebebasan mengemukakan pendapat secara lisan dan tulisan di muka umum, seperti demonstrasi, menyampaikan petisi, menulis buku dan membuat selebaran. Kedua, kebebasan berkumpul seperti mendirikan organisasi termasuk partai politik. Ketiga, kebebasan pers termasuk reportase penyelidikan (investigative reporting) dan penulisan tertentu yang di masa lalu hampir mustahil diperkenankan, yaitu politik dan konflik antar kelompok/golongan. Keempat, pemilu yang bebas, yaitu bebas menggunakan hak/tidakmenggunakan hak dan bebas menjatuhkan pilihan.

Apakah demokratisasi memiliki korelasi signifikan dengan perubahan relasi kekuasaan antara pemimpin dengan rakyat? Dengan kata lain, apakah pola hubungan antara yang memimpin dengan yang dipimpin masih bersifat vertikal dan timpang atau sudah horisontal dan setara? Bagaimanapun juga semboyan demokrasi yang berkumandang sejak Revolusi Perancis ialah kebebasan, kesetaraan dan persaudaraan (liberte, egalite. fraternite). Setidaknya kebebasan sudah dinikmati dan dirasakan bangsa ini. Bagaimana dengan kesetaraan dan persaudaraan? Kesetaraan dan persaudaraan adalah dua sisi mata uang. Tanpa kesetaraan mustahil terjadi persaudaraan. Begitu juga sebaliknya.

Kesetaraan setidaknya ditandai oleh kesamaan hak (equal rights), kesamaan kesempatan (equal opportunity) dan kesamaan kemampuan (equal capacity). Kendati sudah menikmati dan merasakan kebebasan, bangsa ini sadar atau tak sadar belum menikmati dan merasakan kesetaraan dalam pola hubungan antara yanq memimpin dan yang dipimpin. Yang memimpin atau pemerintah dan yang dipimpin atau rakyat di atas kertas memiliki hak dan kesempatan yang sama dalam menjalankan memelihara negara, dan memperoleh manfaat atas sumber daya negeri. Namun, dalam kenyataan, hak dan kesempatan yang sama dapat diwujudkan bita terdapat kemampuan yang sama. Pemerintah memiliki hampir segala kemampuan seperti penguasaan atau akses pada informasi, pengetahuan, sumber daya dan legalitas. Sebagai dasar hukum untuk menjalankan fungsi dan perannya. Sebaliknya, rakyat 
terlalu sedikit untuk mengatakan sama sekati tidak memiliki kemampuan semacam itu. Artinya, demokrasi yang bermakna dan hakiki terjadi ketika pemerintah dan rakyat sama-sama memiliki kesamaan hak, kesamaan kesempatan dan kesamaan kemampuan.

\section{Demokrasi dan Jurang Komunikasi}

Kesamaan hak, kesamaan kesempatan dan kesamaan kemampuan antara pemerintah dan rakyat dalam bentuk konkret dapat dicapai melalui politik. Dalam politik, relasi kekuasaan antara pemerintah dan rakyat dapat dilihat/dievaluasi, apakah setara atau timpang. Kesetaraan pola hubungan antara rakyat yang dalam politik disebut sebagai publik karena publik adalah sekelompok warganegara yang memiliki hak dan kewajiban dan pemerintah dalam bentuk paling nyata dapat diwujudkan melalui partisipasi dalam proses kebijakan. Secara konstitusional kebijakan mengikat warga.

Partisipasi publik dalam proses kebijakan yang mengikat seluruh warga adalah cara efektif untuk mencapai pola hubungan setara antara pemerintah dan rakyat. Di negara-negara demokrasi, partisipasi warga dalam proses kebijakan merupakan hal yang lazim. Partisipasi publik dalam proses kebijakan tidak hanya merupakan cermin demokrasi yang paling nyata dalam kehidupan sehari-hari melainkan juga bermanfaat bagi pemerintah. Permasalahan yang datang silih berganti dan tidak sedikit yang rumit telah membuat pemerintah tidak cukup sensitive atau memiliki waktu menentukan prioritas kebijakan. Keterlibatan masyarakat dalam proses kebijakan membantu pemerintah mengatasi persoalan dalam penentuan prioritas kebijakan. Selain itu, karena masyarakat terlibat dalam proses kebijakan, dengan antusias masyarakat memberikan dukungan terhadap pelaksanaan kebijakan. Bahkan masyarakat berharap agar implementasi kebijakan berhasil baik.

Dalam masa transisi demokrasi yang sedang berjalan saat ini, pemahaman politisi dan birokrat di lembaga eksekutif, legislative dan yudikatif, serta masyarakat termasuk partai politik, bahkan kalangan intelektual dan aktivis demokrasi tentang pentingnya partisipasi publik dalam proses kebijakan masih rendah atau satu sama lain tidak sejalan. Masih terlalu banyak di antara mereka memiliki pola pikir lama bahwa proses kebijakan adalah tugas pemerintah semata karena pemerintah memiliki segalanya: wewenang, fasilitas, sumberdaya, pengalaman, pengetahuan dan informasi. Mereka mengira peran masyarakat dalam sistem demokrasi ialah sekadar bebas berpendapat dan bebas berbeda pendapat bahkan yang sangat keras dan tajam di media massa dan di tempat-tempat umum. Sesederhana dan sedangkal itu. 
Akibatnya, timbul jurang komunikasi antara pemerintah dan masyarakat, sementara permasalahan datang silih berganti, dan permasalahan lama belum mendapatkan solusi yang tuntas.

Para pejabat, politisi dan birokrat mengira bisa mengatasi sendiri segala persoalan. Mereka menutup mata bahwa dalam realitas, utamanya potensi masyarakat begitu besar. Perkembangan sosial-ekonomi dan rnudahnya akses pada informasi menciptakan masyarakat yang memiliki kecakapan dan kekhususan di berbagai bidang profesi. Kenyataan menunjukkan bahwa pemerintah tidak lagi memonopoli peran sebagai regulator, fasilitator dan operator. Makin banyak masyarakat sebagai operator yang memahami, melakukan kegiatan dan berpengalaman di bidang-bidang tertentu seperti pendidikan, kesehatan, transportasi publik, bisnis, dan sebagainya.

Ketika mulai tumbuh kesadaran bahwa pejabat pemerintah memerlukan bantuan masukan (input) dan dukungan masyarakat untuk menemukan solusi, kelompok-kelompok masyarakat yang datang biasanya aktivis lembaga swadaya masyarakat (LSM), intelektual dan pengamat dari perguruan tinggi ternyata tidak mampu memberikan konsep solusi yang komprehensif dan tuntas. Sejauh ini, setumpuk persoalan, tuntutan dan kritik, bahkan cercaan kebanyakan tanpa dukungan argumentasi dan data/informasi yang obyektif, akurat dan rinci adalah yang mereka dapatkan dari kebanyakan aktivis LSM, intelektual dan pengamat. Ini merupakan buah pola pikir lama yang tidak demokratis di kedua belah pihak. Yaitu merasa diri paling benar, paling berhak dan paling mampu mengatur negeri ini, serta paling memperjuangkan nasib rakyat. Utamanya di kalangan LSM tertentu masih kuat pandangan bahwa LSM harus selalu melawan pemerintah karena berdialog dengan pemerintah dapat berarti tidak Independen.

Di kalangan pemerintah masih kuat melekat anggapan bahwa semua LSM bersikap ekstrem, selalu mencari-cari kesalahan pemerintah, dan tidak bisa dipercaya. Yang pasti, kelompok-kelompok masyarakat yang paling lemah biasanya mayoritas penduduk yang tidak mendapat manfaat apa pun, bahkan kerugian, akibat jurang komunikasi antara pemerintah dan masyarakat dan ketiadaan partisipasi publik dalam proses kebijakan.

\section{Membangun Kapasitas Untuk Meningkatkan Kualitas Partisipasi}

Untuk menjembatani jurang komunikasi tersebut, perlu adanya upaya yang tulus dan sungguh-sungguh dari pemerintah di satu pihak dan masyarakat di pihak lain. Bagi pemerintah, 
upaya tersebut bermanfaat untuk mengatasi berbagai persoalan yang ternyata tidak bisa mereka atasi tanpa bantuan, dukungan dan kerjasama masyarakat. Selain itu, globalisasi menuntut pemerintah menerapkan pemerintahanyang bersih (clean gorvernment) dan tata pemerintahan yang baik (good governance). Bagi masyarakat, upaya tersebut bertujuan untuk melaksanakan tanggung jawab mereka sebagai warga negara dan meningkatkan kesejahteraan mereka.

Globalisasi ditandai oleh tiga hal. Pertama, persaingan antarbangsa, antar komunitas dan antar individu untuk memperebutkan sumber daya dan kelangsungan hidup. Kedua, arus informasi yang sulit dibendung sehingga menciptakan keterbukaan dan kesadaran masyarakat (consciousness). Ketiga, pengaruh komunitas dan organisasi-organisasi dan lembaga-lembaga internasional dan regional seperti Perserikatan Bangsa-Bangsa (PBB), Bank Dunia (World Bank), Dana Moneter Internasional (International Monetary Fund), Organisasi Perdagangan Dunia (World Trade Organization) serta negara-negara industri maju. Pemerintahan yang bersih dari korupsi dan tata pemerintahan yang baik berkaitan satu sama lain. Tata pemerintahan yang baik ditandai oleh transparansi manajemen publik, akuntabilitas publik dan partisipasi publik.

Transisi demokrasi telah membuka mata kita semua bahwa persoalan yang dihadapi sangat beraneka ragam, sementara tuntutan untuk memperoleh solusi atas persoalan meningkat cepat. Namun, ternyata kelemahan pemerintah dan masyarakat banyak. Apakah hanya pemerintah yang perlu menerapkan transparansi, akuntabilitas dan partisipasi? Bagaimana dengan lembaga- lembaga dan organisasi-organisasi masyarakat termasuk LSM? Kelemahan pemerintah dan masyarakat tersebut dapat diatasi mulai dengan upaya meningkatkan kualitas partisipasi public yang secara bersamaan akan meningkatkan kualitas transparansi dan akuntabilitas publik-melalui peningkatan kapasitas mereka. Melalui partisipasi, kesetaraan pola hubungan kekuasaan antara pemimpin dan yang dipimpin demokrasi yang bermakna dan hakiki dapat diciptakan. Partisipasi yang paling konkret sekaligus bermakna ialah yang dalam proses kebijakan meliputi identifikasi masalah perumusan masalah alternatif pemecahan masalah putusan kebijakan impiementasi kebijakan monitoring/evaluasi kebijakan identifikasi masalah.

Upaya pembangunan kapasitas makin relevan dan mendapatkan momentum dengan palaksanaan otonomi daearah sejak 2001 berdasarkan Undang-Undang (UU) No. 32 tahun 2004 tentang Pemerintah Daerah dan UU No. 33 tahun 2004 tentang Perimbangan Keuangan Pusat-Daerah. Inti otonorni daerah ialah mendekatkan layanan publik (public services) kepada 
masyarakat melalui pemberdayaan pemerintah daerah dan masyarakat. Khusus untuk memberdayakan masyarakat, terdapat Bab X pasal 53 dalam Undang-Undang tahun 2004 tentang Pedoman Pembentukan Peraturan Perundang-Undangan dengan adanya hak masyarakat memberikan masukan untuk penyiapan dan pembahasan RUU serta Rancangan Peraturan Daerah (Ranperda) walaupun peran masyarakat belum signifikan. Boleh dikatakan kedua UU dan satu RUU tersebut merupakan pemberdayaan pada tataran kebijakan dan tataran politis. Pemberdayaan pada tataran potitis dan tataran kebijakan tidak berarti apa-apa tanpa implementasi.

Pemberdayaan di tataran implementasi dilakukan dengan membangun kesadaran (awareness) tentang pentingnya partisipasi publik, serta membagikan (sharing) dan menyebarluaskan (dissernination) pengetahuan tentang proses kebijakan tidak hanya di elemen-elemen masyarakat tetapi juga kalangan pejabat dan birokrasi pemerintahan. Bersamaan pada tahap pembangunan kesadaran, perlu dibangun saling percaya (trust building) di antara pemerintah dan masyarakat, sesama instansi dan pejabat/aparat pemerintah, dan sesama elemen masyarakat. Selama ini terjadi egoisme sektoral di antara sesama pemerintah, dan kecurigaan di antara pemerintah dan masyarakat.

\section{Permasalahan Kapasitas Publik}

a. Pemahaman masyarakat akan partisipasi publik.

Secara umum dapat dikatakan bahwa masyarakat cukup memahami bahwa tanpa partisipasi publik secara signifikan dalam proses kebijakan maka nasib dan masa depan masyarakal tidak cerah. Namun partisipasi publik menghadapi kendala serius pada kenyataannya disebabkan oleh beberapa faktor. Faktor pertama umunya disebabkan oleh pejabat pemerintah dan anggota legislatif tidak bersedia berdialog dengan masyarakat. Kedua, pejabat pemerintah bersikap diskriminatif dengan mengistimewakan kelompok atau perorangan tertentu, yaitu ekonomi kuat atau yang dekat dengan pusat kekuasaan. Ketiga, posisi tawar masyarakat dalam menghadapi pemerintah sangat lemah karena tidak ada mekanisme sanksi atau pemaksa bagi aparat pemerintah yang tidak menggubris imbauan, keluhan, pendapat, usul dan aspirasi masvarakat. Keempat, tekanan politik yang kuat, misalnya berbentuk protes massal/ demonstrasi yang besar atau dengan cara anarkhis sehingga menimbulkan perhatian luas, ternyata berpeluang lebih besar mendapat perhatian pemerintah. Kelima, legislatif relatif lemah ketika berhadapan dengan eksekutif. Walaupun 
wewenang legislatif di masa kini jauh lebih besar daripada di masa lalu, lembaga yang secara konstitusional merupakan penyerap dan penyalur aspirasi rakyat ini kerap kalah dalam perdebatan dengan para pejabat eksekutif dalam berbagai sidang di legislatif. Selain itu, fraksi-fraksi bahkan anggota dalam satu fraksi sulit mencapai kesamaan sikap, lazimnya karena memiliki kepentingan yang beraroma politik uang (moneypolitics).

b. Partisipasi masyarakat dalam advokasi kebijakan.

Partisipasi ini berkaitan dengan upaya terencana, terorganisasi dan terkoordinasi baik oleh sekelompok atau beberapa kelompok masyarakat untuk mempengaruhi kebijakan atau keputusan tentang alokasi sumber daya politik, ekonomi dan sosial yang berpengaruh pada masyarakat luas. Meski menyadari bahwa advokasi kebijakan sangat penting untuk meningkatkan kesejahteraan masyarakat luas, namun pada kenyataannya masyarakat tidak mampu melakukan advokasi kebijakan karena beberapa faktor. Pertama, masyarakat tidak memiliki cukup pengetahuan, informasi, sarana dan dana untuk menjalankan advokasi kebijakan. Kedua, advokasi merupakan kegiatan yang memerlukan waktu sehingga memerlukan ketekunan, konsistensi, kesabaran dan kegigihan, serta jangka yang panjang juga membutuhkan waktu dan dana lebih besar. Sementara itu, masyarakat cenderung mengharapkan hasil yang segera/instan. Ketiga, masyarakat terpecah-pecah (fragmentasi) dalam berbagai kepentingan dan kelompok dengan latar belakang suku, agama/keyakinan, tingkat sosial- ekonomi, daerah/ wilayah tempat tinggal dan pekerjaan/profesi/fungsi. Tidak ada komunikasi politik atau jaringan sosial yang menghubungkan satu kelompok dan kelompok lain di dalam masyarakat. Dengan demikian tanpa pengorganisasian dan koordinasi baik antar berbagai kelompok/elemen masyarakat, advokasi kebijakan sulit dijalankan.

c. Turut serta menganalisis kebijakan.

Kapasitas yang diharapkan adalah masyarakat terlibat dalam pengkajian atas rencana kebijakan, substansi kebijakan dan implementasi kebijakan pemerintah dengan tujuan membuat kebijakan yang meningkatkan kesejahteraan masyarakat luas secara adil. Dalam pandangan penulis secara umum masyarakat sudah menyadari bahwa memahami analisis kebijakan adalah bagian upaya peningkatan kapasitas agar secara bermutu mampu terlibat dalam proses kebijakan. Akan tetapi dalam kenyataannya menghadapi banyak kendala. Pertama, analisis kebijakan membutuhkan kecakapan tertentu. Ada yang berpendapat bahwa analisis kebijakan merupakan kerja ilmiah/ akademis, sedangkan sebagian besar masyarakat 
berpendidikan rendah. Kedua, kegiatan analisis kebijakan memerlukan data, informasi, dokumen/ referensi yang sesuai (misalnya berbagai kebijakan pemerintah), kemampuan memahami data, informasi, dokumen/referensi. Ketiga, tidak mudah memperoleh data, informasi, dokumen/referensi karena tidak tersedia di toko buku, perpustakaan di daerah, dan aparat pemerintah cenderung menolak permintaan masyarakat akan data, informasi, dokumen/referenei tersebut dengan dalih sebagai rahasia negara.

\section{KESIMPULAN}

Apabila pemerintah dan masyarakat menyadari bahwa demokrasi bukan hanya mengenai perbedaan pendapat dan kebebasan menyampaikan pendapat tetapi pada esensinya, yaitu bersama-sama menemukan solusi yang tepat atas suatu persoalan melalui partisipasi publik secara nyata dan bermutu dalam seluruh tahap proses kebijakan niscaya persoalan rumit dan beraneka ragam dapat lebih mudah diatasi bersama. Partisipasi publik dapat terwujud jika kapasitas pemerintah dan masyarakat ditingkatkan. Dengan cara itu bangsa ini menjadi lebih dewasa, bijak, cerdas dan rasional dalam menyikapi dan mengatasi berbagai persoalannya.

\section{Kemungkinan solusi yang ditawarkan}

Dari pengamatan penulis ada kemungkinan beberapa solusi yang dapat ditawarkan demi menyikapi beberapa kendala yang dihadapi dalam peningkatan kapasitas partisipasi publik dalam proses kebijakan yang terjadi di negara tercinta ini.

1. Membentuk forum dialog/konsultasi antar warga masyarakat (citizen forum) yang meliputi seluruh elemen masyarakat dengan latar belakang dan kepentingan yang berbeda. Pejabat/ aparat pemerintah dan anggota legislatif sebagai pribadi adalah juga warga masyarakat sehingga mereka perlu terlibat aktif seperti anggota lainnya di dalam forum konsultasi antar warga tersebut. Sebagai pribadi, mereka juga terikat pada kebijakan pemerintah, selain juga berkepentingan untuk menikmati layanan publik yang berkualitas sebagai hasil kebijakan pemerintah. Mereka juga perlu menyadari bahwa tidak selamanya mereka adalah pejabat/aparat pemerintah dan anggota legislatif yang rnemperoleh fasilitas dan keistimewaan (privilege). Forum dialog warga semacam itu bertujuan membahas kepentingan bersama tanpa membeda-bedakan latar belakang dan kepentingan masingmasing kelompok rnasyarakat, membuka komunikasi polltik dan membangun saling 
pengertian sekaligus kepercayaan di antara semua kelompok masyarakat termasuk dengan pemerintah, dan membagikan lnformasi/ pengetahuan yang bermanfaat untuk mencari solusi atas berbagai persoalan dan untuk meningkatkan kualitas serta ekfektivitas partisipasi dalam proses kebijakan.

2. Menghimpun dan menyediakan data yang sesuai dengan permasalahan dan isu yang akan mereka sikapi. Data yang lengkap/rinci, obyektif, bisa dipertanggungjawabkan, tepat dan terbaru akan berguna bagi semua pihak pemerintah dan masyarakat yang melakukan dialog, konsultasi dan debat. Data semacam itu diperoleh melalui suatu penelitian dan pengkajian yang ilmiah. Data berguna dalam pembuatan kebijakan. Terbukti bahwa kebijakan tanpa berdasarkan data tidak dapat dilaksanakan dengan baik sehingga wibawa pemerintah merosot.

3. Membangun kerjasama resmi atau tidak resmi sesuai dengan kebutuhan dan kemampuan dengan berbagai pihak yang memiliki kompetensi dan spesialisasi tertentu sesuai bidangnya. Dengan adanya kerjasama, kekurangan/kelemahan yang satu akan dapat dipenuhi oleh yang lain. Misalnya, untuk keperluan penelitian, kerjasama dilakukan dengan peneliti yang sesuai dengan bidangnya. Begitu juga dengan mereka yang rnengerti tentang karnpanye melalui media massa, hukum/peraturan-perundangan, perencanaan kota, transportasi kota, dan seterusnya. Forum konsultasi berguna untuk rnemperoleh informasi tentang mereka yang memiliki kompetensi dan spesialisasi. Bila diperlukan, kerjasama bisa bersifat lintas batas daerah. Kerjasama yang baik akan membuat masyarakat bisa memenuhi kebutuhan sendiri dengan segala keterbatasan tanpa menunggu belas kasihan pihak lain termasuk pemerintah.

4. Mengutamakan cara-cara, tatakrama dan kebiasaan sesuai dengan nilai dan norma yang berlaku di daerah dalam menyampaikan sikap tentang suatu permasalahan atau isu berkenaan dengan kebijakan pemerintah. Penyampaian sikap didasarkan data dan informasi yang lengkap/rinci, objektif, bisa dipertanggungjawabkan dan tepat. Demonstrasi yang tertib dan berdasarkan peraturan merupakan cara terakhir untuk mendorong penentu kebijakan agar bersedia melakukan dialog. Demonstrasi merupakan hak masyarakat untuk menyatakan pendapat dan menyampaikan kehendak. 


\section{DAFTAR PUSTAKA}

Namawi, Hadari. (1993). Metode Penelitian Bidang Sosial. Yogyakarta: PT Gadjah Mada University Press

Calise, Mauro and Theodore J. Lowi. (2010). Hyperpolitics: An Interactive Dictionary of Political Science Concept. Chicago: The University of Chicago.

Huntington, Samuel P. dan Joan Nelson. (1990) Partisipasi Politik di Negara Berkembang. Jakarta: Rineka Cipta.

Magstadt, Thomas M. (2012). Understanding Politics. Belmont: Cengage Learning.

UU No. 32 tahun 2004 tentang Pemerintah Daerah dan UU No. 33 tahun 2004 tentang Perimbangan Keuangan Pusat- Daerah 